\title{
Women cancer prevention and pharmaceutical contribution
}

\author{
Andrezza Viviany Lourenço \\ South Parana Institute of Oncology
}

\begin{abstract}
In Brazil, many cases of breast and cervical cancers are only diagnosed in advanced stages. Information on prevention of cancer in women is increasingly available. However, prevention or early treatment alternatives are often not practiced. This study investigated the issues hindering the practice of prevention against cancer in women. A qualitative method was employed in this exploratory and descriptive study. The sample included thirty-three randomly selected women undergoing treatment. The survey data was collected at the South Parana Institute of Oncology, Ponta Grossa - PR in September 2007 using a semi-structured individual interview after approval by the Research Ethics Committee of the Brazilian College of Systemic Studies - CBES, Curitiba - PR, under protocol 0462/07, in compliance with CNS Resolution number 196/96. Absence of symptoms, embarrassment, long waiting list for treatment, and indifference to the campaigns of prevention were some obstacles encountered. A lack of information about cancer and its causes and consequences was the biggest issue found regarding the acceptance of prevention of cancer in women. The pharmacist, in the role of educator in the prevention of cancer in women, can emphasize the importance of regular prevention practices and highlight the implications of late treatment, disseminating information that can have greater impact on society.
\end{abstract}

Uniterms: Pharmaceutical care. Cancer/prevention. Breast cancer. Cancer/uterine cervix.

No Brasil, muitos casos de câncer de mama e de colo uterino são diagnosticados em estádios avançados. Informações sobre prevenção de câncer na mulher são cada vez mais frequentes. No entanto, prevenção do câncer na mulher e diagnóstico precoce da doença muitas vezes não se realizam. Investigaram-se as causas que dificultam a prevenção de câncer na mulher por método qualitativo sob modalidade exploratória e descritiva. A amostra incluiu trinta e três mulheres em tratamento, selecionadas ao acaso atendidas no Instituto Sul Paranaense de Oncologia, Ponta Grossa - PR, em setembro de 2007, por meio de entrevista semi-estruturada individual com aprovação do Comitê de Ética em Pesquisa do Colégio Brasileiro de Estudos Sistêmicos - CBES, Curitiba - PR, sob o protocolo 0462/07, cumprindo-se a Resolução CNS no ${ }^{\circ}$ 196/96. Ausência de sintomas, vergonha, longa espera em filas de atendimento e indiferença às campanhas de prevenção foram alguns obstáculos encontrados. Carência de informação sobre câncer, suas causas e consequências, foi a maior questão encontrada quanto à aceitação da prevenção do câncer na mulher. O farmacêutico como educador na prevenção de câncer na mulher pode ressaltar a importância dessa prática feita de modo regular e apontar implicações de tratamentos tardios, difundindo informações que causem maior repercussão social.

Unitermos: Atenção farmacêutica. Câncer/prevenção. Câncer de mama. Câncer de colo uterino.

\section{INTRODUCTION}

The World Health Organization (WHO, 2008) reports that about $30 \%$ of cancers can be prevented by modifying or preventing major risk factors. The practice of cancer prevention is to increase the number of cases diag-

*Correspondence: A. V. Lourenço. Instituto Sul Paranaense de Oncologia ISPON, Rua: Francisco Ribas, 638 - 84010-260 - Ponta Grossa - PR, Brasil. E-mail: andrezza@ispon.com.br nosed in the early stages of the disease and hence reduce mortality rates. Prevention is classified depending on the period of the disease that it tackles. Primary prevention is characterized by procedures performed before the onset of the disease, secondary refers to those initiated following onset of the disease course, but without symptoms (Thuler, 2003). In women, cancer prevention is very important, particularly in Brazil where many cases of breast cancer and cervical cancer are diagnosed only at advanced stages (Ministry of Health [INCA], 2005). Breast and cervical 
cancers, respectively, are the main causes of death from cancer in the female population. However, despite the existence of prevention programs around the world, the rate of adherence to such initiatives remains low in many regions (WHO, 2005). But what are the barriers to cancer prevention in women? What are the conditions that hinder or delay the demand for regular medical care?

\section{Breast cancer}

The greatest risk factors contributing to a women contracting breast cancer are related to family and personal history, late reproduction, use of certain drugs, race, and age (CDC, 2007). Factors such as obesity after menopause, breast density, sedentary lifestyle, radiation treatments in breast and alcohol consumption are also relevant and should therefore also be considered (NCI, 2005). More than half of breast cancer cases occur in developed countries due to the aforementioned factors, and high incidence rates occur in part because of good results in the programs of secondary prevention of the disease, which tend to reduce mortality rates (Parkin, Fernandez, 2006). Primary prevention of breast cancer is not fully possible because of genetic factors and the reproduction of independent controls (Ministry of Health [INCA], 2005). In contrast, secondary prevention provides early diagnosis through breast examination and mammography. The current priority in the National Health System (SUS) is the performing of breast examination in clinical practice, and mammography performed in women who present changes on clinical examination.

\section{Cervical cancer}

Cervical cancer is identified as the second most common cancer among women around the world (Ministry of Health [INCA], 2005), corresponding to $15 \%$ of all cancers occurring in women (Martins, Thuler, Valente, 2005). The main cause of cervical cancer is infection by the human papillomavirus (HPV) whose main route of transmission is sexual (NCI, 2005). It should be emphasized that both the rate of incidence and mortality cannot be reduced significantly because about half of all cases are diagnosed at advanced stages (Ministry of Health [INCA], 2003). Cervical cancer is preventable because the development of precursor lesions are slow (Derchain, Longatto, Son, Syrjanen, 2005) as shown in Figure 1. Cases diagnosed at early stages of the disease or as precursors may be cured in all situations (Ministry of Health [INCA], 2004), since cervical cancer is one of the most treatable cancers if identified early and treated effectively (WHO,
2007). Cervical cancer can be completely prevented and curable at a cost, and considered low risk when screening for precursor lesions is associated with the diagnosis, treatment and appropriate medical care (Lewis, 2004). Screening for cervical cancer is accomplished by means of the Papanicolaou test and, according to Brazilian guidelines, the examination should be performed among women in the 25 to 59 year age range (Ministry of Health [INCA], 2005). Primary prevention of cancer must be done through sex education and the elimination of smoking, because, although a secondary factor for cervical cancer, smoking is an important risk factor for other cancers (Ministry of Health [INCA], 2005).

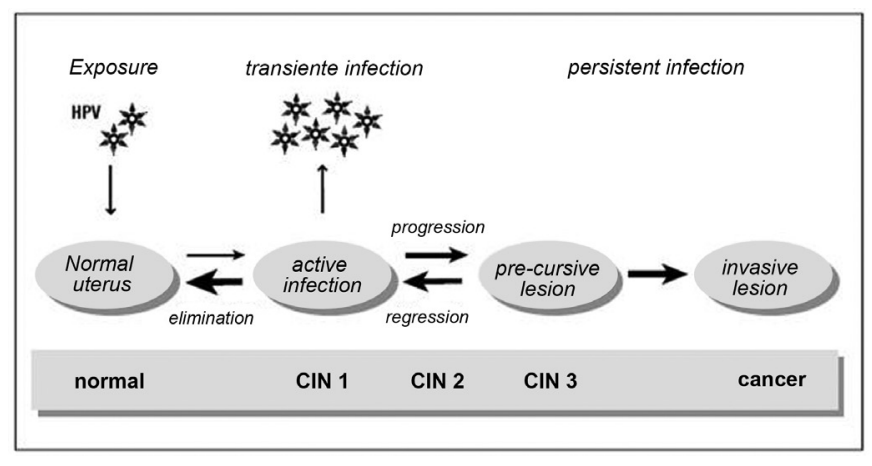

FIGURE 1 - Natural history of cervical cancer. CIN: cervical intraepithelial neoplasia. Adapted from: Cervix cancer screening. Lyon, IARC Press, 2005 (IARC Handbooks of Cancer Prevention, Vol 10).

\section{The role of the pharmacist in cancer prevention}

It is essential that health professionals work toward improving patient care through provision of quality information, expertise and humanism in the profession. The pharmacist must be understood in this context as an educator in the prevention of cancer in women. In fact, there are deficiencies in the health system, in professional preparation, in the way information is transmitted to the population and mainly in the implementation of preventive methods of cancer in women. The pharmacist can and should cater to the needs of society, because the public have shown increasing concern and interest in information on drugs and therapies, as well as in problems related to their health (Zubioli, 2004). Pharmacists must dedicate the time to consider the desires, preferences and needs of the patient in terms of their health, and pharmacists should be committed and continue to focus once practicing (Peretta, Ciccia, 2000). Currently, the Brazilian Consensus on Pharmaceutical Care recommends that this practice is based on health education, guidance, care and dispensing phar- 
macists, as well as on pharmacist therapeutic monitoring, while recording the activities proposed to evaluate results (Vieira, 2007). Pharmaceutical care must be implemented on three basic fronts: pharmacy orientation service, development of skills in the community, and encouraging community action (PAHO, 2002). In identifying healthrelated needs, professionals can develop projects focused on the priorities found in a community, albeit education, information or participation based. However, the pharmacist also contributes little in terms of health education or prevention on diseases such as cancer. The promotion of activities that allow clarification and guidance on cancer prevention is as important as the provision of appropriate treatment for patients with cancer.

\section{MATERIAL AND METHODS}

We used a qualitative method and an exploratory and descriptive approach based on semi-structured individual interview. The questions prepared, both descriptive and inquiry, were applied in the form of pre-structured questions that focused on the issues preventing or hindering access to health care in the prevention of recurrent cancer in women, the obstacles related to early identification and treatment of cancer diagnosed late, and relevance of campaigns to prevent cancer in women in the view of the patients interviewed. Data collection through interviews was carried out exclusively by the lead researcher and took place in September 2007 at the South Parana Institute of Oncology (ISPON) in Ponta Grossa - Paraná State. The sample included 33 women undergoing treatment of breast cancer or cervical cancer under public or private health systems, who were at early or advanced stages. In accordance with Resolution CNS 196/96, the data collection was initiated after project approval by Research Ethics Committee of the Brazilian College of Systemic Studies CBES, Curitiba, protocol number 0462/07. All participants subsequently agreed to take part in writing by signing informed consent forms. The results were structured ba- sed on the concepts proposed by Bardin (cited Triviños, 2006) according to categories of topics covered during the interview in order to better understand the results and characterize the responses given.

\section{RESULTS AND DISCUSSION}

The data obtained in this study showed that problems arise in the prevention of cancer in women vary and can be associated with level of education of each interviewee, insufficient care in the public health system, economic issues and lack of specialists (Table I).

\section{Obstacles related to behavioral habits}

Among the reasons that prevent or hinder access to health care in the prevention of recurrent cancer in women, included the perceived lack of need for medical attention in the absence of symptoms because many women were not familiar with the concept of prevention. E1: Oh dear, I did not feel anything, why go to the doctor? E29: In my day we just resorted to the doctor when something bothered. Do not experience gynecological problems was one reason that contributed to non-regularity of preventive examinations (Pinho, França-Junior, 2003) while screening should be performed in asymptomatic individuals identified as high risk for any given disease (WHO, 2005). The sense of embarrassment was another sentiment associated with resistance in the implementation of preventive examinations of the cervix (Duavy et al., 2007) and the screening of breast cancer by mammography (Marinho et al., 2002). E1: For an old person like me it is hard to pluck up the courage to do these tests. E30: I was too embarrassed to undress in front of the doctor. To this day I am embarrassed to go to the doctor. Exposing one's body to a stranger is one of the important factors, according to the authors, for not carrying out preventive examinations. The lack of sexual activity or age contributes to the failure to perform regular preventive

TABLE I - Barriers to cancer prevention in women

\begin{tabular}{ll}
\hline Obstacles related to behavioral habits & Barriers related to health services \\
\hline Absence of apparent symptoms & Long wait in lines for treatment \\
Embarrassment regarding exams & Lack of professional humanism \\
Advanced age & Delay in test results through public health \\
Lack of time & Late referral to medical oncologists \\
Lack of sexual activity & Lack of oncologists at the health center \\
Fear of results & Poor performance of health workers in preventing cancer \\
Economic factors & \\
Indifference to prevention campaigns & \\
\hline
\end{tabular}


examinations or to discontinuing follow-up (Cesar et al., 2003). Based on data collected in this study, we observed that some women became sexually inactive at the time and thought it unnecessary to go for regular medical attention, where ignoring the association between chronic infection and the human papillomavirus is the main cause for the development of cervical cancer (WHO, 2007). E6: I was not more preventive because I am a widow. E7: As I've been separated a long time, I did not think I needed a doctor. E30: I thought to do preventive checks every year was something for younger women, I went only once in a while. The lack of time to go to the doctor was an equally important reason pointed out by interviewees and is considered a barrier to prevent cancer in women (Pinho, França-Junior, 2003). E2: The problem is that these consultations are time consuming; I cannot take a day off work! E8: Can I get a sick note for this sort of consultation? Lack of availability of time for doctors, not having anyone to leave their children with or being absent at work, were frequent explanations for the women, and their main concern was the fear of giving a bad impression at work because they had left their jobs, even temporarily. Advanced age was also one of the reasons given for not carrying out preventive examinations (Lucarini, Campos, 2007). E8: After my last child was born, I stopped going to consultations. E29: I did not think that at my age the disease would appear. E9: I thought that old people did not need to keep up consultations. Generally, women interviewees aged over 60 did not believe it necessary to perform routine medical prevention because they felt immune from having this type of disease with advancing age. Among the obstacles related to the identification and / or treatment of cancer diagnosed late, was that fear of treatment or the confirmation of the result had become an excuse for some women to ignore the disease. E3: I was afraid of what the family would say, the shock, you know? I did not believe that I had cancer. During cancer treatment, women have emotional, psychological and physical characteristics that affect their lives significantly and for doctor and family it is essential to overcome these effects (Maluf, Mori, Barros, 2005). E13: I was just sick thinking about how horrible it was! Losing my hair? It's even worse when I ask about the disease. From the time of confirmation of the diagnosis of cancer many women go through internal conflicts and denial of the disease and search for other professionals in the hope for an alternative diagnosis (Maluf, Mori, Barros, 2005).

\section{Barriers related to health services}

Some patients complained that during the course of the Papa smear, the lack of dialogue with the health professional creates uncertainty and doubt which are often left unclear. Healths professionals who focus only on the collection and do not perform detailed clinical examination contribute many women not continuing to go for the test (WHO, 2007). E10: I went to consultations every year, but when the doctor and nurse changed I stopped going. The previous doctor was so good to me. The new one does not pay attention to me. E5: The woman who saw me once was so rude that I did not go anymore. The lack of humanism that often occurs in caring for patients before, during and after execution of preventive examinations can be an aggravating factor for both situations of early initial diagnosis and advanced cases of gynecologic cancer. During mammography, a skilled professional must explain the importance of the procedure, how the test is performed, the chances of the patient feeling pain or discomfort, and the patient should be encouraged to answer their questions, allowing her to feel comfortable and confident to return periodically to the doctor (WHO, 2007). Humanism in health is the appreciation of the technical quality and ethics of care, coupled with recognition of the rights of the user, their subjective aspects and cultural references, ensuring that the issues of gender, ethnicity, race, economic status, sexual orientation and specific population groups such as indigenous people, workers, maroon and coastal settlements are respected (Ministry of Health, 2006). Reasons associated with late cancer treatment included the long wait for appointments or test results under the public health system and the delay in referral performed by a non-oncologist. The long wait for appointments or test results prevents the effective participation of women in prevention programs, causing lost interest, leading to lack of participation in programs (PAHO, 2004) and thus delays in commencement of treatment (Lucarini, Campos, 2007). E15: I was feeling pain and I still had to wait two, three months to see the doctor! It's absurd. E22: My problem was the delay in the arrival of checks made out by SUS. E22: I thought that preventive testing was more expensive. So I waited a while to see the result. In the case of late referral to the oncologist, patients who were attended by a non-specialist reported not having been examined at any time during the implementation of preventive examinations. Other women, in regular consultation with the gynecologist, said the referral to specialists occurred only after the symptoms worsened when the idea or suspicion of cancer was raised by the patients themselves or family and after non-pharmacological treatments failed to produce remission of symptoms. E18: My gynecologist said I had a cyst in my breast. The problem is that the cyst was growing and left liquid inside. Then he got scared and 
TABLE II - Proposed guidance on interventions for the prevention of cancer in women

\begin{tabular}{ll}
\hline 1) Concepts of cancer & 2) Guidelines on the prevention of cancer \\
\hline What is cancer & What is cancer prevention and who is at risk \\
What is breast cancer & Prevention of breast cancer \\
What is cancer of the cervix & Prevention of cervical cancer \\
Importance of early diagnosis & Existing screening and its implementation \\
Symptoms (apparent or otherwise) & Regularity of preventive examinations \\
Types of treatments for breast and cervical cancer & Implementation of preventive examinations in public and private \\
Benefits x adverse reactions associated with cancer treatments & services \\
Specialists involved in oncology & Causes of breast cancer and cervical cancer (risk factors) \\
\hline
\end{tabular}

sent me. E11: I saw eight different doctors and they said that I had nothing serious wrong with my breast. I lost a lot of time. E31: I went to see the doctor, but I dealt with the discharge for a few months as if it were an infection. I had never done preventive checks and he also asked me nothing about it. When I got worse and started to bleed, I decided to change doctors.

This situation occurs often for lack of information or knowledge by the professionals. Doctors, not oncologists, have limited knowledge about preventive measures recommended (Tucunduva et al., 2004), although they are key professionals in the prevention and early detection of cancer. Doctors and not oncologists consider the lack of other professional employees and their own lack of knowledge or training as key factors in the adequacy of the recommendations on cancer prevention (Tucunduva et al., 2004).

The main reasons given by women who do not perform preventive examinations (Papanicolaou test) are related to the need for health services to be more effective educational practices and to strategies to decrease the insufficient coverage of the examination, especially for socially vulnerable and dependent on public health care (Amorin et al., 2006). It is essential to educate the public and health professionals to recognize signs and symptoms of early cancer in order to contribute to cancer identification at early stages, in a bid to increase the chances of success in the recommended treatment (WHO, 2005). Preventive education is necessary to ensure better coverage of prevention programs for cancer that can have a greater impact on population (Lucarini, Campos, 2007). E16: Yes, I think prevention campaigns are very important but they should appear more often on TV. E31: Isolated campaigns on TV do not resolve it, we need broader and better performance of health workers.

Factors such as ignorance of the causes that lead to the development of cancer, and understanding the importance of Papanicolaou smears, the concept that cancer is a fatal disease, that prevention is useless and the idea that the cost of the Papanicolaou smear is very high, are some of the reasons given by women who ignore the prevention and early identification of cancer (Lazcano-Ponce et al. cited Cesar et al., 2003). Other studies on breast cancer and cervical cancer have associated with the factors described above, the direct relationship between the nonexecution of preventive examinations with low cultural level of women (Amorin et al., 2006; Marchi, Gurgel, Fonsechi-Carvasan, 2006). The lack of timely and accurate information about cancer in women (Cesar et al., 2003; Maluf, Mori, Barros, 2005; Dalcuche, 2006) sometimes creates misconceptions about the disease. There is a need to overcome beliefs such as the myth that cancer is curable or fatal in any situation, that there are possible treatments or the disease manifests in those it chooses to and that prevention is useless (Cesar et al., 2003).

Pharmacists can act as health teams by tracking health problems of individuals at risk in communities through campaigns to warn of the disease, enabling diseases to be prevented by counseling individuals to make wiser choices about health (Soares, 2002). Pharmacists have the mission to serve society in accordance with the needs of the public at large and of individual patients, and pharmacy practice includes not only activities related to medicines but also directly related to the patient, aimed at promoting health and preventing disease (WHO, 2006).

Based on these data, a roadmap was proposed containing relevant information to foster cancer prevention in women (Table II) through various activities such as lectures, discussions and informative materials. The pharmacy and health facility can become a benchmark in the contribution to cancer prevention in women through participation of pharmacists in disseminating information related to cancer prevention in women.

\section{CONCLUSION}

Despite the existence of educational campaigns and programs for prevention of breast and cervical cancer, 
many women ignore cancer prevention for lack of knowledge about the disease, its consequences and complications, or due to personal barriers. In this study, all patients interviewed stated they were aware of the prevention campaigns against cancer in women. However, some interviewees reported they only realized the severity and importance of cancer prevention when they had to face it personally. Our results suggest that the quantitative survey data in this study be compared to findings of other studies, toward possible improvements in prevention campaigns, the health system and in women's behavioral habits. The educational actions on cancer prevention in women should highlight the real risks and consequences of a lack of regular medical follow-up, through actions designed to have continuous and broader social repercussions.

\section{RERERENCES}

AMORIN, V. M. S. L.; BARROS, M. B. A.; CÉSAR, C. L. G.; CARANDINA, L.; GOLDBAUM, M. Fatores associados à não realização do exame de Papanicolaou: um estudo de base populacional no município de Campinas, São Paulo, Brasil. Cad. Saúde Pública, v.22, n.11, p.2329-2338. Rio de Janeiro, 2006. Available at: http://www.scielosp.org/pdf/ csp/v22n11/07.pdf. Accessed on: 29 jun. 2007.

CENTERS FOR DISEASE CONTROL AND PREVENTION. Breast cancer. CDC, 2007. Available at: http://www.cdc. gov/cancer/breast/ . Accessed on: 22 jun. 2007.

CESAR, J. A.; HORTA, B. L.; GOMES, G.; HOULTHAUSEN, R. S.; WILLRICH, R. M.; KAERCHER, A.; IASTRENSKI, F. M. Fatores associados à não realização de exame citopatológico de colo uterino no extremo Sul do Brasil. Cad. Saúde Pública, v.19, n.5, p.1365-1372. Rio de Janeiro, 2003. Available at: http://www.scielo.br/pdf/csp/ v19n5/17808.pdf. Accessed on: 11 abr. 2007.

DALCUCHE, M. G. A experiência de mulheres com câncer do colo de útero no sistema único de saúde: uma análise sociológica. Curitiba, 2006. [Dissertação de Mestrado em Sociologia. Setor de Ciências Humanas, Letras e Artes. Universidade Federal do Paraná]. Available at: $<$ http://dspace.c3sl.ufpr.br:8080/dspace/ bitstream/1884/4297/1/A\%20experi\%c3\%aancia\%20 de $\% 20$ mulheres $\% 20$ com $\% 20$ cancer $\% 20$ do $\% 20$ colo $\% 20$ do $\% 20$ utero $\% 20$ uma $\% 20$ analise $\% 20$ sociologica $\% 20$ UFPR\%202006.pdf>. Accessed on:02 set. 2007
DERCHAIN, S. F. M.; LONGATTO FILHO, A.; SYRJANEN, K. J. Neoplasia intra-epitelial cervical: diagnóstico e tratamento. Rev. Bras. Ginecol. Obst., v.27, n.7, p.425-433. Campinas, 2005. Available at: <http://www. scielo.br/scielo.php?script $=$ sci_issuetoc $\&$ pid $=0100$ $720320050007 \& \operatorname{lng}=$ pt\&nrm=iso $>$. Accessed on: 20 jun. 2007.

DUAVY, L. M.; BATISTA, F. L. R.; JORGE, M. S. B.; SANTOS, J. B. F. A percepção da mulher sobre o exame preventivo do câncer cérvico-uterino: estudo de caso. Ciênc. Saúde Colet., v.12, n.3, p.733-742. Rio de Janeiro, 2007. Available at: $<$ http://www.scielo.br/pdf/csc/v12n3/24.pdf $>$. Accessed on: 20 jun. 2007.

LAZCANO-PONCE, E. C.; CASTRO, R.; ALLEN, B.; NAJERA, P.; ALONSO-DE-RUIZ, P. A.; HERNANDEZAVILA, M. Barriers to early detection of cervical-uterine cancer in Mexico. In: CESAR, J. A.; HORTA B. L.; GOMES, G.; HOULTHAUSEN, R. S.; WILLRICH, R. M.; KAERCHER, A.; IASTRENSKI, F. M. Fatores associados à não realização de exame citopatológico de colo uterino no extremo Sul do Brasil. Cad. Saúde Pública, v.19, n.5, p.1365-1372. Rio de Janeiro, 2003. Available at: <http:// www.scielo.br/pdf/csp/v19n5/17808.pdf >. Accessed on: 11 abr. 2007.

LEWIS, Merle J. Análisis de la situación del cáncer cervicouterino en América Latina y el Caribe. Lista de Temas. Cáncer cervicouterino. Washington: Organización Panamericana de la Salud; 2004. Available at: $<$ http:// www.paho.org/Spanish/AD/DPC/NC/pcc-cc-sit-lac.pdf>. Accessed on: 29 jun. 2007.

LUCARINI, A. C. B. S.; CAMPOS, C. J. G. A procura pela realização do exame preventivo de citologia oncótica: um estudo clínico-qualitativo. Braz. J. Nurs., Rio de Janeiro, v.6, n.0, 2007. Available at: http://www.uff.br/objnursing/ index.php/nursing/article/view/671/156. Accessed on: 20 jul. 2007.

MALUF, M. F. M.; MORI, L. J.; BARROS, A. C. S. D. O impacto psicológico do câncer de mama. Rev. Bras. Cancerol., v.51, n.2, p.149-154. São Paulo, 2005. Available at: <http://www.inca.gov.br/rbc/n_51/v02/pdf/revisao1. pdf $>$ Accessed on: 22 jun. 2007. 
MARCHI, A.A.; GURGEL, M. S. C.; FONSECHI-CARVASAN, G. A. Rastreamento mamográfico do câncer de mama em serviços de saúde públicos e privados. Rev. Bras. Ginecol. Obst., v.28, n.4, p.214-219. Rio de Janeiro, 2006. Available at: <http://www.scielo.br/pdf/rbgo/v28n4/a02v28n4.pdf >. Accessed on: 05 jul. 2007.

MARINHO, L. A. B.; COSTA-GURGEL, M. S.; CECATTI, J. G.; OSIS, M. J. D. O papel do auto-exame mamário e da mamografia no diagnóstico precoce do câncer de mama. Rev. Ciênc. Méd., v.11, n.3, p.233-242. Campinas, 2002. Available at: $<$ http://bases.bireme.br/cgi-bin/wxislind.exe/ iah/online/?IsisScript $=$ iah/iah $. x i s \& s r c=$ google $\&$ base $=$ LIL ACS\&lang $=$ p\&nextAction $=$ lnk\&exprSearch $=339022 \&$ in dexSearch=ID>. Accessed on: 29 jul. 2007.

MARTINS, L. F. L.; THULER, L. C. S.; VALENTE, J. G. Cobertura do exame de Papanicolaou no Brasil e seus fatores determinantes: uma revisão sistemática da literatura. Rev. Bras. Ginecol. Obst., v.27, n.8, p.485-492. Rio de Janeiro, 2005. Available at: $<$ http://www.scielo.br/pdf/rbgo/ v27n8/26760.pdf $>$.Accessed on: 29 may 2007.

MINISTÉRIO DA SAÚDE. Departamento de Atenção Básica. Controle dos cânceres do colo do útero e da mama. Brasília, DF, 2006. Caderno de Atenção Básica, n.13. Available at: <http://dtr2004.saude.gov.br/dab/caderno_ab.php>. Accessed: 02 may 2007.

MINISTÉRIO DA SAÚDE. Secretaria de Atenção à Saúde. Instituto Nacional de Câncer. Coordenação de Prevenção e Vigilância. Estimativa 2006: incidência de câncer no Brasil. Rio de Janeiro: INCA, 2005. Available at: <http://www. inca.gov.br/estimativa/2006/versaofinal.pdf $>$. Accessed on: 25 apr. 2007.

MINISTÉRIO DA SAÚDE. Secretaria de Atenção à Saúde. Instituto Nacional de Câncer. Coordenação de Prevenção e Vigilância. Estimativas da incidência e mortalidade por câncer no Brasil 2003. Rio de Janeiro: INCA, 2003. Available at: <http://www.inca.gov.br/estimativas/2003/ versaofinal.pdf $>$. Accessed on: 11 jun. 2007.

MINISTÉRIO DA SAÚDE. Secretaria de Vigilância em Saúde. Secretaria de Atenção em Saúde. Instituto Nacional de Câncer. Coordenação de Prevenção e Vigilância. Inquérito domiciliar sobre comportamentos de risco e morbidade referida de doenças e agravos não transmissíveis: Brasil, 15 capitais e Distrito Federal 2002-2003. Rio de Janeiro: INCA, 2004. Available at: <http://www.inca.gov.br/ inquerito/docs/completa.pdf $>$. Accessed on: 02 jul. 2007.
NATIONAL CANCER INSTITUTE. Breast Cancer. Fact sheet. NCI, 2005. Available at: <http://www.cancer.gov/ cancertopics/types/breast $>$. Accessed on: 18 jun. 2007.

ORGANIZAÇAO PAN-AMERICANA DA SAÚDE. Consenso brasileiro de atenção farmacêutica: proposta. Brasília, OPAS, 2002. Available at: <http://bvsms.saude.gov.br/bvs/ publicacoes/PropostaConsensoAtenfar.pdf $>$. Accessed on: 15 apr. 2007.

ORGANIZACIÓN MUNDIAL DE LA SALUD. Control integral del cáncer cervicouterino: guía de prácticas esenciales. Ginebra: Organización Mundial de la Salud, 2007. Available at: <http://www.who.int/reproductivehealth/publications/es/cervical_cancer_gep/text_es.pdf $>$. Accessed on: 29 jun. 2007.

ORGANIZACIÓN MUNDIAL DE LA SALUD. Unión Internacional Contra El Cáncer. Acción mundial contra el cáncer ;AHORA!. Versión revisada 2005. Ginebra: OMS/ UICC, 2005. Available at: <http://www.who.int/cancer/ media/AccionMundialCancerfull.pdf $>$. Accessed: 10 may 2007.

PARKIN, D. M.; FERNANDEZ, L. M. G.; Use of statistics to assess the global burden of breast cancer. Breast J., v.12, n.s1, p.S70-S80, 2006.

PERETTA, M.; CICCIA, G. Reengenharia Farmacêutica: guia para implementar atenção farmacêutica. Salvador: Ethosfarma, 2000. p.28-43.

PINHO, A. A.; FRANÇA-JUNIOR, I. Prevenção do câncer de colo do útero: um modelo teórico para analisar o acesso e a utilização do teste de Papanicolaou. Rev. Bras. Saúde Mat. Infant., v.3, n.1, p.95-112, 2003. Available at: <http:// www.scielo.br/pdf/rbsmi/v3n1/a12v03n1.pdf >. Accessed on: 10 jun. 2007.

SOARES, M. A. Medicamentos não prescritos: aconselhamento farmacêutico. 2.ed. Lisboa: Associação Nacional das Farmácias - Publicações Farmácia Portuguesa, 2002. 2 v.

THULER, L. C. Considerações sobre a prevenção do câncer de mama feminino. Rev. Bras. Cancerol., v.49, n.4, p. 227-238. Rio de Janeiro, 2003. Available at: <http:/www.inca.gov.br/ rbc/n_49/v04/pdf/revisao1.pdf $>$. Accessed on: 27 jun. 2007.

TRIVIÑOS, A. N. S. Introdução à pesquisa em ciências sociais: a pesquisa qualitativa em educação. São Paulo: Editora Atlas, 2006. 175 p. 
TUCUNDUVA, L. T. C. M.; SÁ, V. H. L. C.; TAE KOSHIMURA, E.; PRUDENTE, F. V. B.; SANTOS, A. F.; SAMANO, E. S. T.; COSTA, L. J. M.; DEL GIGLIO, A. Estudo da atitude e do conhecimento dos médicos não oncologistas em relação às medidas de prevenção e rastreamento do câncer. Rev. Assoc. Méd. Bras., v.5, n.3, p.257-262. São Paulo, 2004. Available at: $<$ http://www.scielo.br/pdf/ramb/v50n3/21655. pdf $>$. Accessed on: 15 jul. 2007.

VIEIRA, F. S. Possibilidades de contribuição do farmacêutico para a promoção da saúde. Ciênc. Saúde Colet., v.12, n.1, p.213-220. Rio de Janeiro, 2007. Available at: http://www. scielosp.org/pdf/csc/v12n1/20.pdf Accssed on: 20 maio 2007.
WORLD HEALTH ORGANIZATION. Cancer. Media Centre. Fact sheet $\mathrm{n}^{\circ} 297$. WHO, July 2008. Available at: $<$ http:// www.who.int/mediacentre/factsheets/fs297/en/index. html>. Accessed on: 10 jul. 2008.

WORLD HEALTH ORGANIZATION; INTERNATIONAL PHARMACEUTICAL FEDERATION. Developing pharmacy practice: a focus on patient care. WHO/ FIP, 2006. Available at: <http://www.who.int/medicines/ publications/WHO_PSM_PAR_2006.5.pdf $>$. Accessed on: 25 jun. 2007.

ZUBIOLI. Ética farmacêutica. São Paulo: Sobravime, 2004. p.63-78.

Received for publication on $24^{\text {th }}$ June 2008 Accepted for publication on $24^{\text {th }}$ August 2009 